\title{
Is it Important to Apply Flipped Learning in Teaching Indonesian to Speakers of Other Languages (TISOL)?
}

\author{
Prima Vidya Asteria \\ Universitas Negeri Surabaya \\ Surabaya, Indonesia \\ primaasteria@unesa.ac.id
}

\author{
Koh Young Hun \\ Hankuk University of Foreign Studies \\ Seoul, Korea \\ ykoh@hufs.ac.kr
}

\begin{abstract}
One question that underlies the birth of the Flipped Learning (FL) model is "What is best for my students in my classroom?" The purpose of this study is to analyze the importance of Flipped Learning in Teaching Indonesian to Speakers of Other Language (TISOL). This research approach is qualitative with descriptive type through literature study method. Data in the form of documents and journals about FL and its applications, and are associated with the author's experience in TISOL. Data were analyzed by triangulation. Based on the analysis, it could be concluded that FL significantly had a positive impact on learning, including TISOL (FL-based TISOL implementations on Hankuk University of Foreign Studies (HUFS) shows that the average score of class with FL is better than the other class with no FL. Moreover, most students were first in the FL class said that they were willing to take FL-based TISOL classes for the second time. TISOL is increasingly in demand, both in Indonesia and abroad, it is necessary to apply FL as an alternative learning model. As an important note, TISOL teachers need to agree that their focus is FL as a model, not just focus on supporting technology. Another thing is the application of FL in TISOL in Indonesia and abroad is certainly different. TISOL implemented in Indonesia needs to be designed with a proportion of less-technological assistance and more direct practice with Indonesian people. On the other hand, TISOL abroad (due to the lack of Indonesian cultural context) needs to be designed with more technology-assisted FL so students have more information about Indonesian and Indonesian.
\end{abstract}

Keywords-flipped Learning; Indonesian Teaching to Speaker of Other Language (TISOL)

\section{INTRODUCTION}

There are significant positive trends in the development of Indonesian language learning as a Foreign Language. This is marked by the increasing number of institutions that hold BIPA programs or BIPA courses, both in Indonesia and abroad.

As a foreign language learning, BIPA learning also needs to be presented usefully and interesting. Useful in terms of content, which can provide the needs of students to achieve certain competencies according to the needs of the BIPA program they follow. Moreover, BIPA learning also needs to be presented in an interesting way with a variety of teaching materials, teaching strategies, teaching methods, evaluation techniques, and teaching media. Several studies related to this issue have been conducted by the authors to prove that the variation of learning components can improve the quality of the process and learning outcomes of BIPA students ${ }^{[1][2]}$

In today's digital era, BIPA instructors are required to master technology to support learning. It is because technology is proven can expand BIPA students' learning opportunities to get various learning resources. Technology does not replace the role of the teacher in the class, instead it becomes a teacher strengthening in packing a BIPA learning package that is interesting and eagerly awaited by students.

In Robinson's opinion, teaching is a form of art at its essence because teachers know each of them (that is, teaching is not mass produced), they also track the students' progress (as sort of "mind readers", teachers know what motivates students and how they respond to teaching, and finally they know what to do at the right moment (they have the skills to apply their knowledge appropriately).

One learning strategy that utilizes technology is Flipped Learning (FL). FL is an educational technique that consists of two parts: interactive group learning activities inside the classroom, and direct computer-based individual instruction outside the classroom ${ }^{[3]}$.

FL can optimize the potential of students and teachers so that both will be motivated in the teaching and learning process. For now, various FL-based learning continues to be developed and researched, included in language learning.

A key element of mixed learning is technology called "turning the class" developed by American educators Jonathan Bergmann and Aaron Sams in $2000^{[4]}$. The idea of this technology is that the main stages of the teaching and learning process such as classroom activities and homework are reversed. Hence, theoretical material is studied by students individually by watching video lectures recorded by teachers or downloaded from Internet websites while class activities are devoted to fulfill practical tasks and discuss major problems with the teachers ${ }^{[5]}$. The purpose of this study was to analyze the importance in applying flipped learning in teaching Indonesian to speakers of other language. 


\section{METHOD}

This study was designed with a qualitative approach to literature review. To answer the importance of FL in Indonesian Language classes for Foreign Speakers, the method used is reviewing the scientific literature and reflecting the pedagogical experience of the author in teaching the BIPA class.

The source of this research data are three papers related to the topic. First, the paper written by Koh Young Hun entitled 'Application of the Flipped Learning Method in Indonesian Language Learning at Korean Universities' which was presented at the BIPA International Symposium in Yogyakarta $2017^{[6]}$. Second, a paper entitled 'Methodology of Flipped Classroom as a Learning Technology in Foreign Language teaching ', written by Kamo Chilingaryan \& Ekaterina Zvareva at the $7^{\text {th }}$ International Conference on Intercultural Education in $2016^{[7]}$. Third, the paper by Arina Evseeva \& Anton Solozhenko entitled 'Use of Flipped Classroom Technology in Language Learning' presented at the XV International Conference 'Linguistic and Cultural Studies: Traditions and Innovations in $2015^{[8]}$.

The collected data is analyzed qualitatively. The process of data analysis was done by arranging the data sequence, organizing it into a category. In order to be in line with the order of the problems that have been established, the data analysis in this study is regulated by stages (1) data identification, (2) data selection, (3) data coding, (4) data classification, and (5) data analysis. At the data analysis stage, several analytical techniques were applied, namely (a) deletion, (b) substitution, (c) form change (paraphrase), (d) expansion, and (e) reversal ( permutation). Various methods and techniques of analysis are attempted to produce a description, explanation, and comprehensive findings about the object under study.

\section{RESULT AND DISCUSSION}

\section{A. Flipped Learning}

The instructor needs to ask himself what is best for his students in his class. This answer can help teachers to plan, implement, and evaluate learning well so that students will truly learn about the material according to their level ${ }^{[4]}$.

Flipped learning is born from teacher anxiety about students who have not been able to capture the content of lectures into useful information that helps them learning and doing homework. Then, the Flipped Learning model was born, Bergman and Aaron recorded all content through videos. Students studied the videotape at home, then the opportunity in class was used for discussing and doing various activities to discuss the concept of material that was not yet understood by students. Flipped Learning is a flexible framework and can be adapted to the context of students and teachers.

Basically, the meaning of FL is what in conventional learning is done in class. Somehow, it is currently done at home. However, what should be done as homework is done in the class. The benefits of FL are to facilitate students who have more activities, increasing student interaction with other students, accommodating a variety of students' abilities, and providing flexible instructions ${ }^{[4]}$.

Aranson and Artstrom's study concluded that the results of FL implementation at the University of British Columbia showed that the presence of students in FL classes had increased by $20 \%$ and had twice the learning outcomes of conventional classes. More importantly, students stated that they enjoyed FL class ${ }^{[9]}$. Furthermore, Berret who also applied FL at the University of Michigan also found student learning outcomes doubled compared to conventional classes [11].

Based on the previous explanation, it is concluded that the benefits of FL are as follows:

1. Optimizing class time.

2. Supporting the development of high-level thinking skills.

3. Increasing teacher-student and student interaction.

4. Facilitating students who have more activities / activities to accommodate a variety of students' abilities.

5. Providing flexible instructions.

On the other hand, there are several challenges related to the application of FL, namely ${ }^{[10]}$ :

1. Behaviorist education at the primary level (elementary / high school) strengthens the role of traditional students / teachers.

2. The inverse learning environment places the "burden" of active learning, especially on the shoulders of students. Teachers must also master the constructivist learning environment.

3. Students must recognize and internalize independent learning skills to be successful. (students who are better motivated and aware)

4. Students / teachers must have internet access and preferably personal computers. (minimum level of computer skills)

To prepare FL-based learning, there are three important things that must be done, namely:

1. The Faculty: Faculty is

a. Purchasing

Is conducted when all faculty components are willing to accept and actively support the FL implementation plan. The application of FL in the first year requires farther preparation than traditional learning. However, online lecture materials can be used in the following years ${ }^{[12][13]}$.

b. Mentoring and training

For FL implementation, faculties need to conduct mentoring and training to prepare human resources so that in the interactive learning approach ${ }^{[14]}$.

2. Infrastructure

Infrastructure in the form of facilities and infrastructure must be provided. Software that is compatible with supporting specifications is needed to smooth online lectures and view student activity history. In addition, the infrastructure that is the biggest challenge is the classroom that is conducive to active learning.

3. Student 
Students need to be given an explanation of reasons and the importance of applying FL-based learning. Faculties or schools need to explicitly mention the benefits that will be gained by students, namely Understanding learning material more quickly, flexible in learning, getting a lot of learning resources $^{[15]}$.

\section{B. Flipped Learning Implementation in TISOL Classes}

If Bergmann and Aaron used video recording as the main source in FL class. The following is a comparison table of the implementation of FL-based learning with traditional learning.

TABLE I. COMPARISON OF CLASS IN TRADITIONAL VERSUS FLIPPED CLASSROOMS ${ }^{[4]}$

\begin{tabular}{|c|c|c|c|}
\hline \multicolumn{2}{|c|}{ Traditional Classroom } & \multicolumn{2}{|c|}{ Flipped Classroom } \\
\hline Activity & Time & Activity & Time \\
\hline $\begin{array}{l}\text { Warm-up } \\
\text { activity }\end{array}$ & 5 min. & $\begin{array}{l}\text { Warm-up } \\
\text { activity }\end{array}$ & 5 min. \\
\hline $\begin{array}{l}\text { Go over } \\
\text { previous night's } \\
\text { homework }\end{array}$ & $20 \mathrm{~min}$ & $\begin{array}{l}\text { Q\&A time on } \\
\text { video }\end{array}$ & $10 \mathrm{~min}$. \\
\hline $\begin{array}{l}\text { Lecture new } \\
\text { content }\end{array}$ & $30-45$ min. & $\begin{array}{l}\text { Guided and } \\
\text { independent } \\
\text { practice and/or } \\
\text { lab activity }\end{array}$ & $75 \mathrm{~min}$. \\
\hline $\begin{array}{l}\text { Guided and } \\
\text { independent } \\
\text { practice and/or } \\
\text { lab activity }\end{array}$ & 20-35 min. & & \\
\hline
\end{tabular}

Meanwhile, Koh Young Hun ${ }^{[6]}$ uses a book / shortcut book application in FL learning. Hankuk University of Foreign Studies (HUFS) has taught Indonesian since 1964 under the name Malay-Indonesian Study Program (PSMI). Youth are no longer interested in foreign language learning in traditional ways. Even though they take longer, they are willing to attend lectures that are more fun than classes that consist of traditional learning elements. Teacher limitations and the Indonesian context as well as the desire to utilize technology in the background learning of FL application in Indonesian classes. Currently the model Flipped Learning is an attractive tool in educational technology ${ }^{[16]}$

Teaching in two classes is distinguished. Class A applied FL with the help of book and e-book applications, while class B was taught traditionally. FL class started with ice breaking so that the atmosphere became fun and was continued with information on how to attend the lecture and how to use the application book. Students learned first before entering class, then follow activities related to it. One way to check that they have learned first or not is to have them teach in another group. When students teach in other groups, the teacher gives advice or gives answers to questions from the participants. There are some students who ask points that have not been understood and there are also those who ask how to use the application related to the lesson.

Generally, students were happy to be given the opportunity to teach their friends in other groups. Furthermore, all students assessed the results of their peer teaching and the best group / student is selected. The best groups / students would be given an appreciation in the form of performance tickets, stationery, and books. Then a question and answer session was followed with points that have not been clearly understood when they study at home. After that, students were given the task of making a video or slide show related to the material. An important point for the success of the program in this class was that the instructor did not explain the related lesson content in the classroom, but does other activities related to the lesson.

Learning outcomes show that FL has a real positive impact on Indonesian Teaching to Other Language (TISOL) on HUFS. This is evidenced by the average value of students in FL 84.2 class while the class without FL has an average value of 76.9). As much as $91.4 \%$ of students were first in the FL class and $94.2 \%$ said they were willing to take FL FL-based TISOL classes again. As many as $88.6 \%$ of all participants consider it effective to learn the content of the lesson at home before entering the class and feel their achievement has developed in Indonesian language learning. Furthermore, $94.2 \%$ of participants gave positive responses. At the end of the semester they are satisfied with their respective learning methods and achievements.

Based on the results of interviews, students stated that FL has the following advantages.

1. Students can repeatedly listen to lectures in the device.

2. Students can also study anywhere if there is time, for example on a bus.

3. Students can use time effectively.

4. Students can submit assignments anywhere and anytime, because there is a platform like iTunes U.

5. Students can practice on their own at home by using the menus contained in the application book.

The explanation above shows the positive results of the application of FL in TISOL. This reinforces the perception that technology can help students learn effectively. Technology helps students become independent in learning individually, become proficient group members (when studying in groups), and can think scientifically ${ }^{[17]}$.

TISOL is increasingly in demand both in Indonesia and abroad, it is necessary to apply FL as an alternative learning model. As an important note, TISOL teachers need to agree that their focus is FL as a model, and not just focus on supporting technology. Another thing that is also important and needs to be studied further is the application of FL in TISOL in Indonesia and abroad is certainly different. TISOL implemented in Indonesia needs to be designed with a proportion of less technological assistance and more direct practice with Indonesian people. On the other hand, TISOL abroad (due to a lack of Indonesian cultural context) needs to be designed with more technology-assisted FL so students have more information about Indonesian and Indonesian. 


\section{CONCLUSION}

Flipped Learning has a real positive impact on learning, including TISOL (the FL-based TISOL implementation on HUFS shows an average student score of 84.2 while the class without FL has an average value of 76.9). As much as $91.4 \%$ of students were first in the FL class and $94.2 \%$ said they were willing to take FL FL-based TISOL classes again. TISOL is increasingly in demand, both in Indonesia and abroad, it is necessary to apply FL as an alternative learning model. Planning, implementation, and evaluation of learning need to be adjusted to the learning context. The Flipped Learning model is an alternative model that can be applied, of course it is also modified by other teachers according to the needs and context of learning. The suggestion for the next researcher is to develop FL-based TISOL by linking Indonesia's cultural context.

\section{REFERENCES}

[1] A. Prima Vidya, BIPA for Business: Peluang Pengajaran BIPA di era MEA. Prosiding Konferensi Internasional Pengajaran BIPA IX di Bali Oktober, 2015.

[2] A. P. Vidya, Pengenalan Permainan Tradisional Indonesia Di Kelas Bipa. Paramasastra, Vol. 4 No. 1 - Maret 2017 p-ISSN 2355-4126 eISSN 2527-8754 http://journal.unesa.ac.id/index.php/paramasastra

[3] J. L. Bishop and M. A Verleger, The Flipped Classroom: A Survey of the Research. American Society for Engineering Education, 2013.

[4] J. Bergmann and Sams, A, Flip your classroom: Reach every student in every class everyday.Washington. DC: International Society for Technology in Education. 2012.

[5] FITZPATRICKJUNE, 2012

[6] Koh Young Hun, Application of the Flipped Learning Method in Indonesian Language Learning at the 2017 Korean College, 2017

[7] K. Chilingaryan \& E. Zvareva, Methodology of Flipped Classroom as a Learning Technology in Foreign Language Teaching. 7th International Conference on Intercultural Education "Education, Health and ICT for a Transcultural World", EDUHEM 2016, 15-17 June 2016, Almeria, Spain, 2017.

[8] A. Evseeva \& A. Solozhenko, Use of Flipped Classroom Technology in Language Learning. XV International Conference "Linguistic and Cultural Studies: Traditions and Innovations", LKTI 2015, 9-11 November 2015. Tomsk, Russia, 2015.

[9] N. Aronson, K.M. Arfstrom, and K. Tam, Flipped learning in higher education, 2013. Retrieved from http://www.flippedlearning.org

[10] Erdem, Aksoy. Flipped Classroom. https://www.google.co.id/url?sa=t\&rct=j\&q=\&esrc=s\&source=web\& $\mathrm{cd}=8 \& \mathrm{cad}=$ rja\&uact $=8 \&$ ved $=0$ ahUKEwis7-

3Sm4PcAhXPb30KHWwZBSwQFghgMAc\&url=https $\% 3 \mathrm{~A} \% 2 \mathrm{~F} \% 2$ Fctl.tedu.edu.tr\% 2Fsites\% 2Fdefault $\%$ 2Ffiles\% 2Fcontent_files\% 2Fdocs $\% \quad$ 2Fflipped_model.pdf \& usg = AOvVaw1OXaxndUJqdMXh9vGWSMm8

[11] D. Barrett, How 'flipping' the classroom can improve the traditional lecture. The Chronicle of Higher Education, Feb. 19, 2012.

[12] Garnham C, Kaleta R. Introduction to hybrid courses. Teaching with Technology Today. 2002:8.

[13] S.P. Ferreri and S.K. O'Connor, Redesign of a large lecture course into a small-group learning course, Am J Pharm Educ. 2013:77. http://dx.doi.org/10.5688/ajpe77113

[14] C.M. Critz and D. Knight, Using the flipped classroom in graduate nursing education, Nurse Educ, 2013; 38 (5): 2103.http://dx.doi.org/10.1097/ NNE.0b013e3182a0e56a

[15] J Carpenter and J. Pease, Sharing the learning. PHI DELTA KAPPAN;94(2):36-41, 2012
[16] A. L. Johnson, S. Becker, V. Estrada, and A. Freeman, NMC horizon report: 2014 higher education edition. Austin. Texas: The New Media Consortium, 2014.

[17] M. T. Al-Hariri and A. A. Al-Hattami. Impact of students' use of technology on their learning achievements in physiology courses at the University of Dammam. Ed. August 2016. Taibah University: Journal of Taibah University Medical Sciences, 2016. 